\title{
Multimodality in Property Commercial: Linguistics Cityscape of Batu
}

\author{
Feny Anggeria, Universitas Airlangga \\ Levinda Hesty Suryawardhani, Universitas Airlangga \\ Dr. Ni Wayan Sartini, Universitas Airlangga
}

\begin{abstract}
Property has always been a topic of discussion for the news media and among Indonesian. In terms of property advertising in Indonesia, the focus of this paper is on the linguistic landscape of Batu City as one of the tourism destinations in Indonesia. This study is a multimodal discourse analysis of commercials which adopts O'Halloran's (2008) and Cheong's (2004) framework towards Generic Structure of Potential of sign in billboards. This analysis represents the interaction between linguistics and visual elements that is analyzed by using GSP's components: visual and linguistics. The data for this study is in the form of photos of billboards which are taken in Batu City. It is obtained by analyzing the sign of public space in 3 different areas of the land. The result of this analysis reveals the relation between ideational and interpersonal metafunction to construct the ideal consumer experience, while the representation reflects the linguistics cityscape of Batu. The result shows that property in rural area tends to use foreign language to express language, while in the city area uses local language or Bahasa Indonesia.
\end{abstract}

Keywords: billboards; GSP; linguistics cityscape; sign

\section{Introduction}

The opportunity of Batu property is one of the challenging work in home industry and commercial business. To explore a property is to gain the right market which advertisement is the new role in public space. As the developer and investor put their rules in the workship, the high demand of residential advertisement is close to a successful number. Batu is known as a tourismcity, with rapidly growing population every year. This is indirectly demands the provisions of dwellings are more and more, so it may cause newcomers prefer choosing and living in Malang. Property in Batu is chosen in this research because the high demand of advertisement and industry becomes a new trend in Indonesia. Most Indoesians nowdays put their effort to own property as their life style and dream for a better living. In addition, Malang tourism increasingly is known by the outside world. Residential property has been attractive to rich Indonesians and other partly as a protection against inflation. To attract the customer's attention, the commercial company creates an advertisement to announce and represent the product that is being advertised. It tries to build the trust to purchase residence. Besides, company wants to make people believe to its product and creates a solution to give people a dream when they buy the residence.

Linguistic Landscape (LL) is 'the use of language in its written form in the public sphere' (Gorter 2006: 2). This written form, especially situated in the public space carries different interpretation, meaning, and semiotic properties from spoken language. Linguistics Landscape is a real and symbolic of reality of such places which performed in the written text and pictures. LL is usually placed in public space. Language in LL is used for both pragmatic and symbolic reasons (Loth, 2016: 2). Language in public space is to give information. On the one hand, using specific language in public space means giving new information to everybody. People who read the billboard have different background of knowledge. This thing is common since any interpretation can be interpreted in a various way. But since the emergence of LL theory take its place, researchers rather use Multimodality to interpret advertisements. 
Property commercial is a different insight to communicate meaning behind the advertisements. The aim of this performance is to send the message behind the text and to attract people through the ideology or meaning on the sign. To attract the customer's attention, the commercial company creates an advertisement to announce and represent the product that is being advertised. It tries to build the trust to purchase residence. Besides, company wants to make people believe to its product and creates a solution to give people a dream when they buy the residence. To explore the intended meaning of Property Commercial in Malang, several theories are used. The first is Systemic Functional MDA (Multimodal Discourse Analysis) by O'Halloran (2008), GSP (Generic Structure Potential by Cheong (2004) that is previously used by Hasan and Halliday (1989) to explore linguistic and visual elements. Intersemiotic Texture (2008) is used, also theory of color and structure composition by Kress and Van Leeuwen (2006) to build a relationship between linguistic and visual elements.

There are two previous studies that used in this research. First, the research that is written by Manan (2017) entitled "The glocalization of English in the Pakistan linguistic landscape. "This study surveys the linguistic landscape in a particular area of Pakistan, and explores the use of languages, and the pervasiveness of English in the localized non-Roman script. Although, English functions as a foreign language for most Pakistanis, it occurs extensively in signage in public places. Following the analysis of multiple data sources such as interviews of businesspeople and photographs of private billboards, wall advertisements, roadside signposts and posters, the results suggest that Englishized Urdu and Urduized English predominate in the linguistic landscape, while local/indigenous language remain completely absent. Second, research entitled Mapping the linguistic landscape of Athens: The case of shop signs (Nikolaou, 2017). A total of 621 shop signs were collected and analyzed both quantitatively and qualitatively. The findings indicate that a significant number of shops employ-often creatively-languages other than Greek, either monolingually or in combination with Greek, resulting in a situation of written multilingualism, with English emerging as the strongest linguistic player. The results also strongly suggest that the multilingual character of commercial signs is not primarily informational but symbolic reflecting a desire to project a cosmopolitan, sophisticated, and trendy outlook.

According to Cheong, the elements of printed advertisement are linguistic and visual elements. The GSP of billboards is used to label and categorize both elements in order to find the intended meaning of the maker of commercial. Below is the interaction between those two elements. The double arrows mean the interaction between linguistic and visual elements in meaning making process. The elements in billboards contain Lead, Display, Emblem, Announcement, Enhancer, Tag and Call and Visit Information. See the Figure 1, below:

Figure 1. The elements in billboards

(source: The Elements in advertisement, O'Halloran (2004: 165))

\begin{tabular}{|c|c|}
\hline $\begin{array}{l}\text { Visual Components } \\
\text { Linguistics Components }\end{array}$ & $\begin{array}{l}\text { Lead: Locus of Attention (LoA), Complement to } \\
\text { the Locus of Attention (Comp.LoA) } \\
\text { Display. Explicit, Implicit, Congruent, } \\
\text { Incongruent (metaphorical) } \\
\text { Emblem } \\
\text { Announcement: Primary, Secondary } \\
\text { Enhancer } \\
\text { Emblem } \\
\text { Tag } \\
\text { Call-and-visit information }\end{array}$ \\
\hline
\end{tabular}

The interaction between linguistic and visual elements in billboards 


\section{Method}

The current paper employs descriptive qualitative method. Denscombe (2007) remarked that the use of words or images as the unit of analysis is more likely to be associated with qualitative research. The data interpreted this study are in the form of images and text in billboards advertising properties in Batu. There are 11 selected advertisements in total collected, spread over three districts in Batu. To collect the data, the documentary method is applied. The data analysis started from labelling and categorizing the element of the advertisement gathered based on Cheong (2004):

a. Lead

The Lead is interpersonally most salient based on the size, colour and its position (Siska.etc., 2017). Lead consists of Locus of Attention (LoA) and Complements to the Locus of Attention (Comp. LoA). LoA is the idea of the sign. It can be an attractive picture of the commercial. Complements to the Locus of Attention have a function to focus the viewer's attention. Product attention is probably the goal of the company. The Interpersonal function of LoA is to attract the attention of the viewers (Cheong, 2004: 165-171).

b. Display

Display represents explicit means picture of a tangible product, implicit means an intangible product or service given tangible form through another medium, congruent means that the product is not realized through symbolism and incongruent means that the product is realized through symbolism (Cheong, 2004: 171).

c. Emblem

The Emblem is a logo of the product and brand name. The function of Emblem is to give identity and status to the product (Cheong, 2004: 171).

d. Announcement

The Announcement explores the message of the advertiser. Announcement consists of Primary and Secondary Announcement (Cheong, 2004: 173).

e. Enhancer

It is one of the components of the advertisement which usually represents through paragraph (Cheong, 2004: 173). Through explaining and describing the product that is related to Lead and Announcement, it improves the quality of the product

f. Tag

Tag is a small printed clause to interact the customer's attention which is not appeared grammatically and usually realized as non-finite (Cheong, 2004: 174).

g. Call an Visit Information

The Call and Visit Information gives information where the customers should buy the product and the detail information of the product. It can be a telephone number, address, email, website so the customers are able to know the details of the commercial. It is placed on the certain parts of the advertisements (Cheong, 2004: 174).

The concept of Generic Structure Potential (GSP) proposed by Cheong is useful for the study of intertextual links between texts. There are some optional elements in any genre which is realized by its context. The GSP model for Systemic Functional Linguistic is suitable for any investigation analyzed any passages and related it with the context in the discourse and general background of the text. Then, after knowing the visual and the verbal element, each element is analyzed and interpreted to be then concluded.

\section{Results and Discussion}

According to Anggraeni (2017, in Cheong, 2004) GSP of printed advertisement consists of two categories, they are linguistic and visual elements (p.16). The visual elements are Lead, Display, and Emblem, the linguistic elements are Announcements, Enhancer, Tag, Emblem, and Call and Visit Information. Here is the result of Malang Billboard using GSP analysis: 
Table 1: The result of Malang Billboard using GPS

\begin{tabular}{|c|c|c|c|c|}
\hline Number & $\begin{array}{c}\text { The Printed } \\
\text { Advertisements }\end{array}$ & $\begin{array}{c}\text { Visual } \\
\text { Elements }\end{array}$ & Linguistic Elements & $\begin{array}{c}\text { Element } \\
\text { Absent }\end{array}$ \\
\hline 1 & Griya Taman Asri & Lead:LoA, & $\begin{array}{c}\text { Primary\& } \\
\text { Announcement, Tag, } \\
\text { Call \& Visit } \\
\text { Information, Emblem }\end{array}$ & $\begin{array}{c}\text { Enhancer, } \\
\text { Comp.LoA, } \\
\text { Emblem } \\
\text { (visual) }\end{array}$ \\
\hline 2 & Troya Batu Residence & $\begin{array}{l}\text { Lead: LoA, } \\
\text { Comp.LoA, } \\
\text { Emblem }\end{array}$ & $\begin{array}{l}\text { Primary\& Secondary } \\
\text { Announcement, } \\
\text { Enhancer, Call \& Visit } \\
\text { Information, Emblem }\end{array}$ & Tag \\
\hline 3 & Batu Top View & $\begin{array}{l}\text { Lead:LoA, } \\
\text { Emblem1, } \\
\text { Emblem } 2\end{array}$ & $\begin{array}{c}\text { Primary\& Secondary } \\
\text { Announcement, } \\
\text { Emblem, Tag, Enhancer } \\
\text { 1, Enhancer 2, Enhancer } \\
\text { 3, Call \& Visit } \\
\text { Information, Emblem }\end{array}$ & Comp.LoA, \\
\hline 4 & Batu Panorama & $\begin{array}{l}\text { Lead:LoA, } \\
\text { Emblem }\end{array}$ & $\begin{array}{l}\text { Primary Announcement, } \\
\text { Tag, Call \& Visit } \\
\text { Information, Emblem }\end{array}$ & $\begin{array}{l}\text { Comp.LoA, } \\
\text { Enhancer }\end{array}$ \\
\hline 5 & Kayana Regency & $\begin{array}{l}\text { Lead:LoA, } \\
\text { Emblem }\end{array}$ & $\begin{array}{l}\text { Primary\&Secondary } \\
\text { Announcement, Tag, } \\
\text { Emblem, Call \& Visit } \\
\text { Information }\end{array}$ & $\begin{array}{l}\text { Comp.LoA, } \\
\text { Enhancer }\end{array}$ \\
\hline 6 & Emerald Villas & $\begin{array}{l}\text { Lead:LoA, } \\
\text { Emblem }\end{array}$ & $\begin{array}{c}\text { Primary\&Secondary } \\
\text { Announcement, } \\
\text { Enhancer 1, Enhancer 2, } \\
\text { Emblem, Call \& Visit } \\
\text { Information }\end{array}$ & $\begin{array}{l}\text { Comp:LoA, } \\
\text { Tag }\end{array}$ \\
\hline 7 & Kings Park & $\begin{array}{l}\text { Lead: LoA, } \\
\text { Emblem }\end{array}$ & $\begin{array}{c}\text { Primary\& Secondary } \\
\text { Announcement, } \\
\text { Emblem, Enhancer1, } \\
\text { Enhancer 2, Call \& Visit } \\
\text { Information, Emblem }\end{array}$ & $\begin{array}{l}\text { Comp. LoA: } \\
\text { Tag }\end{array}$ \\
\hline 8 & Batu Panorama & $\begin{array}{l}\text { Lead: LoA, } \\
\text { Comp. LoA, } \\
\text { Emblem }\end{array}$ & $\begin{array}{l}\text { Tag, Call \& Visit } \\
\text { Information, Emblem }\end{array}$ & $\begin{array}{c}\text { Primary\& } \\
\text { Secondary } \\
\text { Announcement, } \\
\text { Enhancer } \\
\end{array}$ \\
\hline 9 & Dharma Permata & $\begin{array}{l}\text { Lead: LoA, } \\
\text { Comp. LoA }\end{array}$ & $\begin{array}{c}\text { Primary\& Secondary } \\
\text { Announcement, Tag, } \\
\text { Enhancer }\end{array}$ & $\begin{array}{l}\text { Tag, Emblem } \\
\text { (visual) }\end{array}$ \\
\hline 10 & KusumaPesanggrahan & $\begin{array}{l}\text { Lead:LoA, } \\
\text { Comp.LoA, } \\
\text { Emblem1, } \\
\text { Emblem2, } \\
\text { Emblem } 3 \\
\end{array}$ & $\begin{array}{l}\text { Primary\&Secondary } \\
\text { Announcement, Tag, } \\
\text { Emblem (linguistic), } \\
\text { Call \& Information 1, } \\
\text { Call \&Information 2 } \\
\end{array}$ & Tag \\
\hline 11 & Perum. Dewi Sartika & Lead: LoA & $\begin{array}{c}\text { Primary\&Secondary } \\
\text { Announcement, Emblem } \\
\text {,Call \& Information }\end{array}$ & $\begin{array}{c}\text { Comp. LoA, } \\
\text { Emblem } \\
\text { (visual), Tag, } \\
\text { Enhancer }\end{array}$ \\
\hline
\end{tabular}




\subsection{Kusuma Pesanggrahan}

Figure 2. Billboard at Kusuma Pesanggrahan

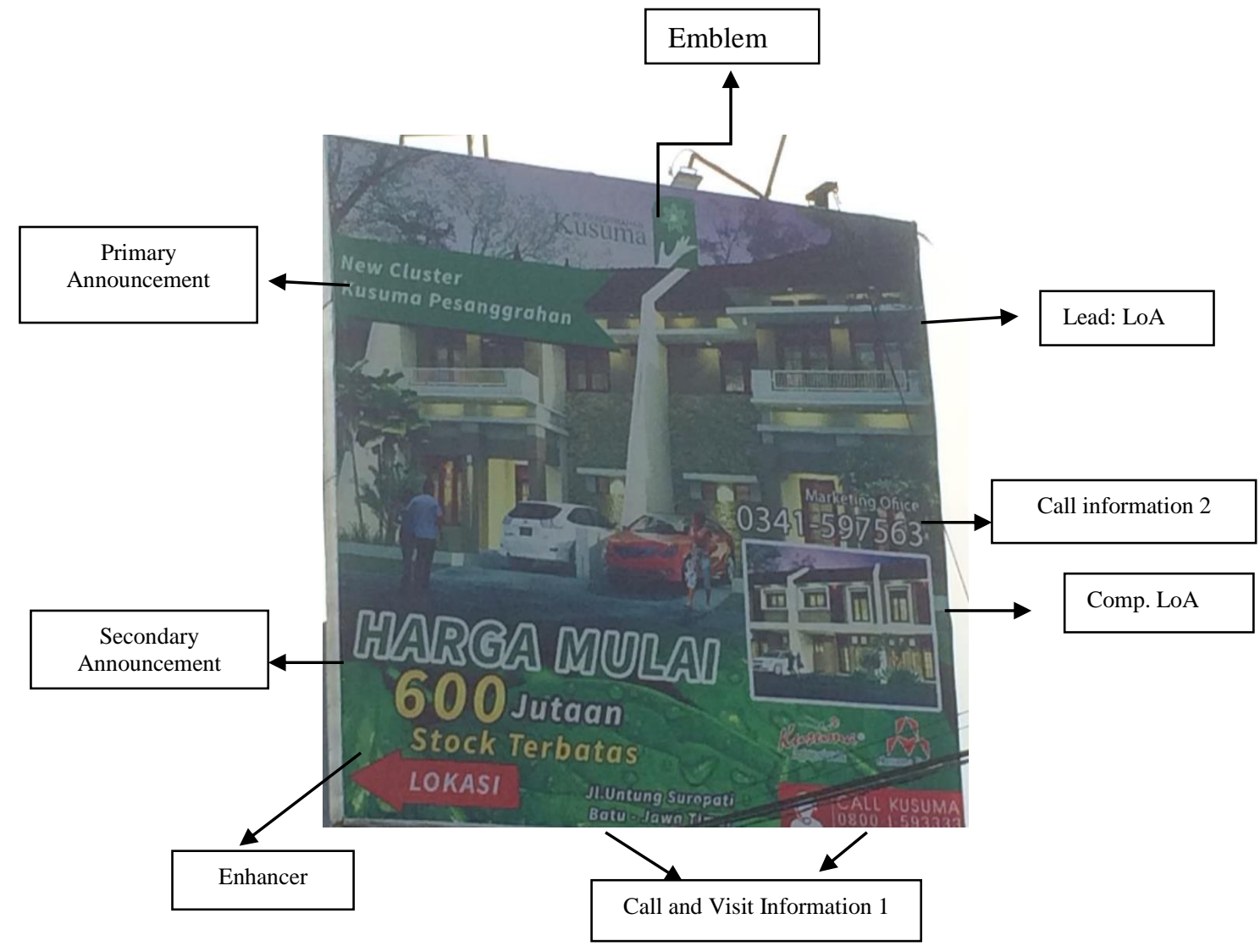

New cluster Kusuma Pesanggrahan

The Lead: LoA is positioned in the center side of billboards. It shows a large real-estate which mostly covers the picture. Its purpose is to deliver the real and prestigious product that share the advertiser's idea. The position of the sign brings meaning that the advertiser tries to show that the model is popular and has been known by the customers (Kress \& van Leeuwen, 2006: 180). Interestingly, the colour of billboards is dominantly green. Perhaps the representation of nature and environmental performance is the important reality of the product. Leaves which represents the green atmosphere connects the customer's need which want to own the house. It's important to analyze its meaning. Colour naturalism, in contrast, is situated against the backdrop of a loss of conventional, or semiotic, uses as colour became more of an embellishment, a way of achieving naturalistic effects, of recapturing the world as it appears to the eye (Bateman, 2011). The Comp. LoA / Display displayed as the house is located on the bottom-right hand side of the advertisement depicted with new or different unit. Kress and van Leeuwen (2006: 180) stated that the key information that the customers must pay attention to. The product has gold colour which means rich, glory, and luxury. The Emblem is positioned on the top-right side. It tells the name of the company Kusuma Pesanggrahan as green and white flower, also open hand inside the logo. The use of 'white' as the written text represents a cleansing and purifying of the emotions, thoughts, spirit, refreshing and strengthening of the entire energy system (Kress \& van Leeuwen, 2006: 234). The open or give hand tries to tell that the company surely give the best service and sincerity to the customers. It can be said, when one believes to buy one unit, the customers are going to experience the meaning behind the logo. Green colour defines that leaf has green colour which becomes the subject of 'green' 
itself that means purity (Kress \& van Leeuwen, 2006: 234). The green leaf interprets the global warming, nature, plant, earth. It proves that the product is a co-friendly home. The Announcements are positioned on the left side. The Primary Announcement 'New Cluster Kusuma Pesanggrahan' comes first and it is written on bold type with white colour. White refers to the cleansing and purifying of the emotions, thoughts, spirit, refreshing and strengthening of the entire energy system (Kress \& van Leeuwen, 2006: 234). The Secondary Announcement 'HARGA MULAI 600 Jutaan' has a straight message about the price of the unit. The Enhancer is told by the word 'Stock Terbatas' which means the quality of product in a limited numbers. The Call and Visit Information is positioned on the center. Through this position, it means that the advertiser tries to provide more specific information that already known by the customers (Kress \& van Leeuwen (2006: 180).

\subsection{Batu Top View Residence}

Figure 3. Billboard at Batu top view residence

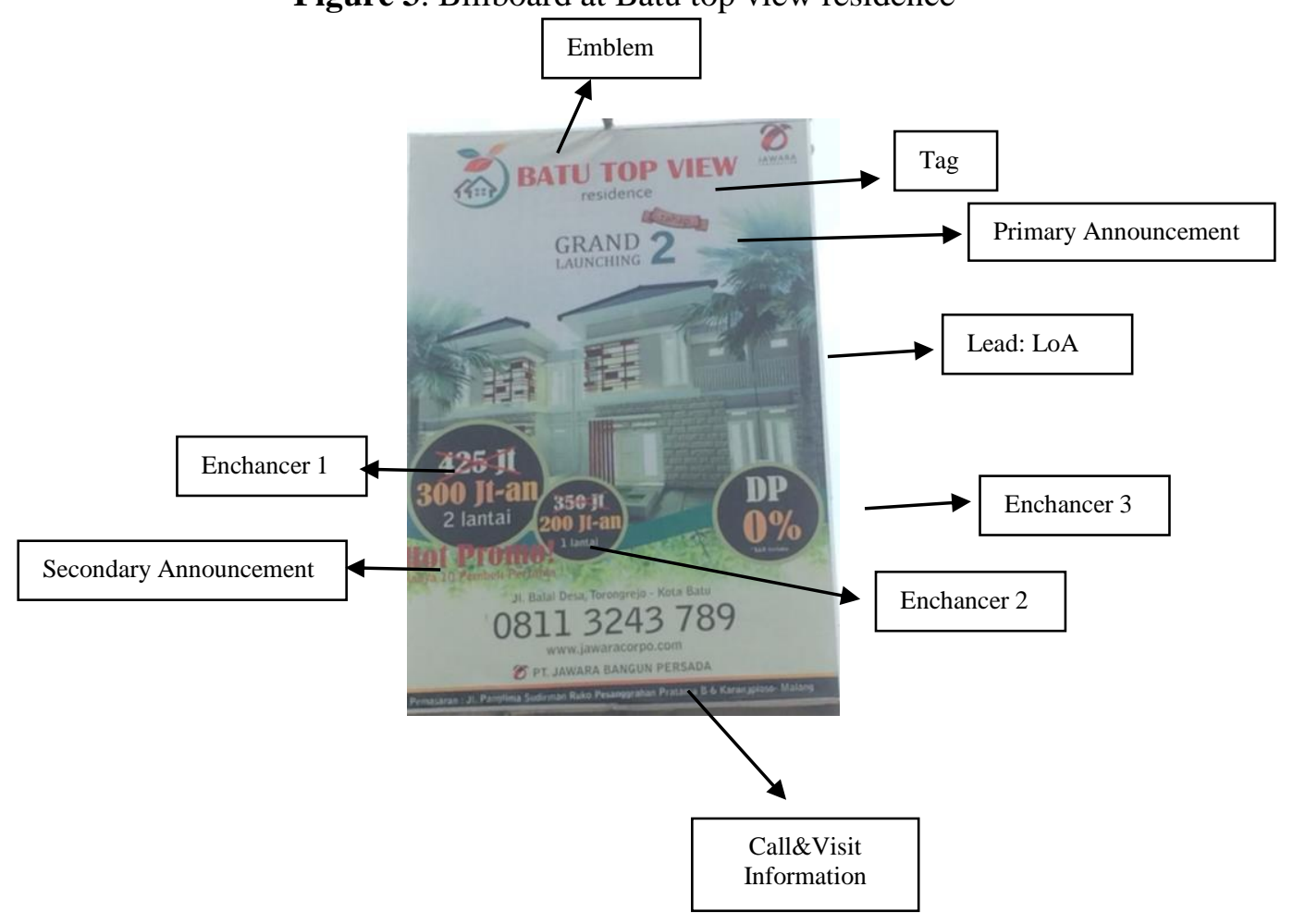

The center side of billboards at Batu top view residence

The Lead: LoA is positioned in the center side of billboards. It shows a large real-estate which mostly covers the picture. Its purpose is to deliver the real and prestigious product that share the advertiser's idea. The position of the sign brings meaning that the advertiser tries to show that the model is popular and has been known by the customers (Kress \& van Leeuwen, 2006: 180). Interestingly, the colour of billboards is dominantly white and green. The Comp. LoA. The use of 'white' as the written text represents a cleansing and purifying of the emotions, thoughts, spirit, refreshing and strengthening of the entire energy system (Kress \& van Leeuwen, 2006: 234). Tag 'residence' performs as a small word which tries to inform that this type of real-estate is a residential type. For location, this unit is in rural area of Malang, while people understand less about the name. The Primary Announcement 'Grand Launching 2' gives message that this product is the second unit that has been success in previous launching. Secondary Announcement 'Hot Promo Hanya Pembeli Pertama' has slight 
information that the promo is launched in limited time and limited number of people. The Call and Visit Information is positioned on the center below. The enhancer mentions 3 times which means the advertiser tends to describe what promo includes the unit and what the benefit of the product.

\section{Conclusion}

Attractive and creative billboards are the key to shape viewer's ideology while they first see or just look the billboards on the road because one sight can deliver a widely great opportunity to the advertisers. To attract the customer's attention, the concept idea of Batu Cityscape represents short and straight clauses. These clauses are aimed to attract viewers to purchase the product, and to gain a benefit feedback for owning the house unit. In addition, Property in Batu tends to use two languages which are Bahasa Indonesia and English. This is used because advertisers agree and understand that most of people in the place have a good knowledge of English language. The strategy of using word combination is because advertisers know exactly their market and who the persons are. They want to share to the public that the more they use English in it, the more the products are seen as a fast moving unit in a high demand location. In the city, where it does not have much tourism, the use of word combination is less necessary. People rather understand a local language because they viewers mostly use Javanese rather than Bahasa Indonesia or English.

In the village area, Comp. LoA is mostly an absent element. It means that property billboards only need 1 presented picture that has been labeled in Lead: LoA. People already know the unit, without Comp: LoA they simply get attention in a direct and fast way. Meanwhile, in city area, billboards have a various missing elements. Under local background, people are easier with a large picture so they can feel the joy and comfort towards the billboards. Picture with representation of family has an ability to increase the desire of the buyers of purchasing the units.

The property billboards apply two dominant colours: white and green. White is for clean air, purity, while green is for nature and environmental performance. The language characteristics tell viewers that LL shapes viewers with cityscape ideology. It also creates the attitude of people who want to stay and own house in Batu.

\section{References}

Bateman, J. 2011. The language of colour: the language of the o van leeuwen. Germany: Bermen University.

Cheong, Y. Y. 2004. The construal of ideational meaning in printed advertisements. In O‘Halloran, K. L (ed.). Multimodal Discourse Analysis: Systemic Functional Perspectives. London and New York: Continuum.

Denscombe, M. 2007. The good research guide: for small-scale social research projects. $3 \mathrm{rd}$ $e d$. Open University Press.

Gorter, D. 2006. Introduction: The study of the linguistics landscape as a new approach to multilingualism. Amsterdam: Fryske Akademy / Universities van Amsterdam.

Kress, G. \& Van Leeuwen, T. 2006. Reading images: The grammar of visual design. London and New York: Routledge.

Loth, C. R. 2016. The linguistic landscape as construct of public space: A case study of postapartheid rural South Africa. South Africa: University of The Free State.

Manan, S. A., David, M. K., Dumanig, F. P., \& Channa, L. A. 2017. The glocalization of english in the pakistan linguistic landscape. world englishes, 36(4), 645-665.

Nikolaou, A. 2017. Mapping the linguistic landscape of athens: the case of shop signs. International Journal of Multilingualism, 4(2), 160-182.

O'Halloran, K. L. 2008. Systemic functional-multimodal discourse analysis (sf-mda): construing ideational meaning using language and visual imageri. visual communication, vol. 7, pp. 443-475. 
O’Halloran, K. L., \& Smith, B. A. 2013. Multimodal text analysis. Singapore: National University of Singapore.

O’Halloran, K. L. 2005. Mathematical discourse: language, symbolism and visual images. London and New York: Continuum.

Siska, A., etc. 2017. Exploring the eco discourse in seventh generation's printed advertisements: A systemic functional multimodal discourse analysis. 